\title{
The impact of Business Support Instruments on the innovation activity of medium-high and high technology manufacturers in Poland
}

\author{
Piotr Dzikowski ${ }^{1, *}$ \\ ${ }^{1}$ University of Zielona Góra, 50 Podgórna St., 65-246 Zielona Góra, Poland
}

\begin{abstract}
The article shows the impact of Business Support Instruments (BSIs) on the innovative activity of medium-high and high technology manufacturers in Poland. The analysis includes 1355 industrial enterprises representing medium-high and high-level technology based in Poland. The scope of the research concerns innovation at company-level and takes into account the diffusion to the "new for the company". The work assumes that the innovative activity of MHT \& HT manufacturers grows as a result of interaction with BSIs. Technological parks and business consulting centers have the greatest positive impact on stimulating innovation activity.
\end{abstract}

\section{Introduction}

There has been a growing trend among researchers and policymakers to facilitate business creation and technology transfer by providing various public Business Support Instruments (BSIs) including science and technology parks, business and technology incubators and both publicly and privately financed loan and guarantee schemes $[1,2,3]$.

The aim of BSIs initiatives is to promote entrepreneurship, innovation and the development of new technology-based firms [4, 5]. Furthermore, BSIs create a bridge between research and industry [6], act as catalysts for the transfer of knowledge and technology, thereby facilitating and accelerating innovation processes [7] and embed the companies in entrepreneurial networks [8]. Due to many successful BSI implementations in both developed $[9,10]$ and developing countries [11] the impact of BSIs on economic growth and regional development has been widely recognized. However, there is a lack of research including the survey of influence of BSIs on innovation activity, in middle-sized converging economy such as Poland $[12,13,14,15]$. We consider converging economies as countries having the infrastructure of developed countries yet lagging behind in innovation performance.

Our central proposition is to investigate the impact of BSIs on innovation activity of medium-high and high technology manufacturers in Poland. It is argued that the innovative activity of the analyzed group of enterprises grows as a result of interaction with business support instruments.

\footnotetext{
*Corresponding author: p.dzikowski@,wez.uz.zgora.pl
} 
The research consists of a logit analysis based on 1355 enterprises representing medium-high and high technology manufacturers from Poland. The study contains the period of five years from 2008 to 2013.

The results include two perspectives of innovation activity: research and development expenditure $(\mathrm{R} \& \mathrm{D})$ and financial investments and product and process implementations.

The findings suggest that technological parks and business consulting centers have the most significant positive impact on stimulating innovation activity.

In the following section, a brief review of the BSI literature is presented, followed by a description of the study method and a brief overview of the logit methods. Next, results of the logit analysis are introduced. The paper ends with conclusions, limitations, and main implications of this research.

\section{Literature review}

BSIs consist of various mutual complementary forms of public support including technology or business incubators, innovation or technology centers, science or research or technology parks, business or seed accelerators, and financial support in the form of government loan guarantees, public loan programs, and equity investments. Although the literature contains a plethora of definitions [16], there is a lack of a universal definition so we introduce and characterize each instrument apart. Early definitions of small business incubators define these instruments as centers that help young companies to grow in their early stages by providing those newcomers with a rental space, shared office, and assistance through business consulting services [17]. [18] view an incubator as "... a supportive environment for start-up and fledgling companies". [19] understand incubators as facilities that house young, small firms to help them develop quickly into competitive businesses. A large number of definitions include four fundamental features:

1. shared office space, which is rented under more or less favorable conditions to incubates,

2. a pool of shared support services to reduce overhead costs,

3. professional business support or advice and

4. network provision, internal and/or external [20].

According to [21] the concept of business incubation evolved since the establishment of the first incubators, but academic research has accompanied this evolution although most published studies are descriptive and use no consistent theoretical lens. The first generation of incubators emphasize real estate provision and the second generation include intangible services [22]. In contrast, the latest generation of incubators typically focus on new technology-based firms and are expected to reduce the risk-of-death of newcomers. [23] distinguishes five types of incubators: mixed, economic development, technology, social and basic research incubators. There are significant differences in the type of innovation emanating from each type of incubator [24]. According to [25] there is no uniformly accepted definition of a science park, and there are several similar terms used to describe similar developments such as "research park", "technology park", "business park", "technopole", but each of these terms is used to describe: (1) a property-based initiative close to a place of learning, and (2) one which provides high quality units in a pleasant environment. Science parks are established to stimulate the formation and development of new technology-based firms [26] as well as knowledge transfer arising from universities and R\&D institutions [27]. The different developments patterns and a wide variety of shareholders and founders of science parks have contributed to the formation of the very heterogeneous organization, with an important difference being the degree of involvements of a university in the park. Hence, it is possible to identify parks in which there is university shareholding, that we may call Science Parks and parks in which the 
university is not involved in the ownership of the park, that we may call technology parks [28].

The literature predicts that SMEs have general access problems and pay a premium on borrowing. However, for high-technology firms, those challenges are even higher [29]. Furthermore, high-technology firms are perceived to be more risky than other, so financial institutions take this into account when designing loan contracts [30]. According to [31] the numerous loan guarantee programs have been conceived to allow lenders to share with the government the risk of default on outstanding loans and covering any potential loss. Some results from various countries suggest that lower spreads are offered for loans of larger amounts and higher durations, for service firms, for larger firms, and for those located in the most advanced regions. On the other hand, higher spreads are applied to high-tech manufacturing firms and loans issued for working capital purposes [32]. In converging economies including the Polish economy, loan funds with lower provision achieve better results. For guarantee funds, the value of the guarantee and the number of cooperating banks are the most important for their achievements [33]. In contrast, private owned instruments containing venture capitalists and business angels are driven by the performance of high-tech start-ups receiving financing. The experience of business angels in early-stage investments is positively associated with additional receipt of follow-on rounds of financing and sequential capital injections from venture capitalists. However later-stage experience is positively associated with the start-ups- success but reduces the need for new venture capitals to invest in the start-up [34].

[35] distinguishes between product and process innovations. Product innovation can be subdivided into product and service [36]. On the other hand, process innovation can be subdivided into technological and organizational innovation [37]. According to [38] process innovation directly influences on the structure of the organization, but indirectly affects the introduction of new products through a change in the production process [39]. Innovation activities are all activities that support innovation including three areas: expenditure on research and development (R\&D) and investments (i.e., purchase of machinery, equipment, land, and buildings), product and process implementations, and cooperation within innovation [40].

\section{Methodology}

The scope of the research relates to innovation activity in medium-high (MHT) and high technology (HT) manufacturers in Poland. It concerns both product and process innovations new only to the firm. Data contain the period from 2008 to 2013. The main instrument of the survey is a questionnaire distributed by email. Furthermore, a telephone interview was conducted with the owner or manager. Explained variables include R\&D expenditure, investments in new fixed assets including buildings and land, machinery and technical equipment and computer software, implementations of new or improved products or technological processes, including production methods, nonproduction systems, and support systems. In turn, explanatory variables consist of technology parks, technology incubators, university incubators, technology transfer centers, business angels networks, local or regional loan schemes, guarantee schemes and business consulting centers. In this study, the model of logistic regression is estimated to assess whether and at which level each of the independent variables contributes to each kind of innovation activity [41]. The multinomial logit model estimates the effects of explanatory variables on a dependent variable with unordered response categories [42, 43, 44]. The significance of the independent variable coefficients is tested by using the Wald test, and it is considered a valid coefficient for the model when the level of statistical significance is $p<0.05$. The calculations are performed in Statistica Software. 


\section{Results}

The dataset contains 1355 manufacturers from Poland, including 424 micros (31.29\%), 453 small (33.43\%), 341 medium (25.17\%) and 137 large (10.11\%) entities. The most numerous set includes domestic enterprises 1104 (81.55\%). On the other hand, foreign capital represents 142 companies $(10.48 \%)$, and mixed capital is represented by 108 enterprises $(7.97 \%)$. Table 1 . shows the structure of firms due to the manufacturing sector.

Table 1. The structure of firms due to the manufacturing sector.

\begin{tabular}{|l|c|}
\hline \multicolumn{1}{|c|}{ Sector } & $\begin{array}{c}\text { Number of } \\
\text { firms/Share(\%) }\end{array}$ \\
\hline $\begin{array}{l}\text { Manufacture of instruments and appliances for measuring, testing and } \\
\text { navigation; watches and clocks }\end{array}$ & $187(13,80)$ \\
\hline $\begin{array}{l}\text { Manufacture of basic pharmaceutical products and pharmaceutical } \\
\text { preparations }\end{array}$ & $60(4,43)$ \\
\hline Manufacture of communication equipment & $70(5,17)$ \\
\hline Manufacture of computers and peripheral equipment & $52(3,84)$ \\
\hline Manufacture of air and spacecraft and related machinery & $5(0,37)$ \\
\hline Manufacture of machinery and equipment & $480(35,42)$ \\
\hline Manufacture of electrical equipment & $227(16,75)$ \\
\hline Manufacture of chemicals and chemical products & $156(11,51)$ \\
\hline Manufacture of motor vehicles, trailers and semi-trailers & $82(6,05)$ \\
\hline Manufacture of other transport equipment & $21(1,55)$ \\
\hline Manufacture of railway locomotives and rolling stock & $15(1,11)$ \\
\hline Total & $1355(100)$ \\
\hline
\end{tabular}

In contrast to investments in new fixed assets $(78,2 \%)$ and implementation of new technology processes $(76,2 \%)$, both investments in buildings and land $(28,2 \%)$ and implementations of new support systems $(30,1 \%)$ are the least frequently taken activities. Table 2. includes Research and Development expenditure (R\&D) model. Technology transfer centers increase odds of taking $R \& D$ expenditure 3.17 times while technology incubators and technology parks increase odds respectively 2.55 times and 2.60 times. Business consulting centers increase a probability of taking R\&D expenditure the least. Firms maintaining contacts with technology centers have more than twice higher odds to take R\&D expenditure than firms cooperating only with business consulting centers.

Table 2. R\&D expenditure (R\&D) model.

\begin{tabular}{|l|c|c|c|c|c|}
\hline \multicolumn{7}{|c|}{ Chi-square $=\mathbf{6 1 . 9 4 6 ,}$ P-value $=\mathbf{0 . 0 0 0 0}$} \\
\hline Variable & Coefficient & $\begin{array}{c}\text { Standard error } \\
\text { (SE) }\end{array}$ & $\begin{array}{c}\text { Wald chi- } \\
\text { square }\end{array}$ & $\begin{array}{c}\text { P- } \\
\text { value }\end{array}$ & $\begin{array}{c}\text { Odds } \\
\text { ratio }\end{array}$ \\
\hline Technology parks & 0.9572 & 0.2298 & 17.3469 & 0.0000 & 2.60 \\
\hline $\begin{array}{l}\text { Technology } \\
\text { incubators }\end{array}$ & 0.9378 & 0.4060 & 5.3343 & 0.0209 & 2.55 \\
\hline $\begin{array}{l}\text { Technology transfer } \\
\text { centers }\end{array}$ & 1.1556 & 0.2512 & 21.1601 & 0.0000 & 3.17 \\
\hline
\end{tabular}




\begin{tabular}{|l|c|c|c|c|c|}
\hline \multicolumn{7}{|c|}{ Chi-square $=\mathbf{6 1 . 9 4 6 ,}$ P-value $=\mathbf{0 . 0 0 0 0}$} \\
\hline $\begin{array}{l}\text { Business consulting } \\
\text { centers }\end{array}$ & 0.3509 & 0.1545 & 5.1571 & 0.0234 & 1.42 \\
\hline
\end{tabular}

Table 3. includes Investment in New Fixed Assets (INFA) model. Guarantee schemes, as well as cooperation with technology parks, support investments in new fixed assets the most respectively 2.91 and 2.36 times. On the other hand, both technology transfer centers and business consulting centers increase odds of investment 1.97 each.

Table 3. Investment in New Fixed Assets (INFA) model.

\begin{tabular}{|c|c|c|c|c|c|}
\hline \multicolumn{6}{|c|}{ Chi-square $=48.258, P$-value $=0.0000$} \\
\hline Variable & Coefficient & $\begin{array}{c}\text { Standard error } \\
\text { (SE) }\end{array}$ & $\begin{array}{l}\text { Wald chi- } \\
\text { square }\end{array}$ & $\begin{array}{c}\text { P- } \\
\text { value }\end{array}$ & $\begin{array}{l}\text { Odds } \\
\text { ratio }\end{array}$ \\
\hline Technology parks & 0.8586 & 0.3130 & 7.5231 & 0.0060 & 2.36 \\
\hline $\begin{array}{l}\text { Technology transfer } \\
\text { centers }\end{array}$ & 0.6233 & 0.3076 & 4.1048 & 0.0427 & 1.87 \\
\hline Guarantee schemes & 0.6242 & 0.2105 & 25.7645 & 0.0000 & 2.91 \\
\hline $\begin{array}{l}\text { Business consulting } \\
\text { centers }\end{array}$ & 1.0684 & 0.2670 & 5.4689 & 0.0193 & 1.87 \\
\hline
\end{tabular}

Table 4. includes Investment in Buildings and Land (IBL) model. Cooperation with technology incubators decreases investments in buildings and land nearly 0.30 times. The most facilitating instrument seems to be cooperation with business angels - nearly 2.5 times higher odds. Relatively supportive are technology parks, guarantee schemes, and business consulting centers increase in odds from 1.51 to 1.86 .

Table 4. Investment in Buildings and Land (IBL) model.

\begin{tabular}{|l|l|c|c|c|c|}
\hline \multicolumn{7}{|c|}{ Chi-square $=\mathbf{2 7 . 2 8 9}$, P-value $=\mathbf{0 . 0 0 0 0}$} \\
\hline Variable & Coefficient & $\begin{array}{c}\text { Standard } \\
\text { error (SE) }\end{array}$ & $\begin{array}{c}\text { Wald chi- } \\
\text { square }\end{array}$ & $\begin{array}{c}\text { P- } \\
\text { value }\end{array}$ & $\begin{array}{c}\text { Odds } \\
\text { ratio }\end{array}$ \\
\hline Technology parks & 0.6210 & 0.2196 & 7.9960 & 0.0047 & 1.86 \\
\hline Technology incubators & -1.2478 & 0.5508 & 5.1311 & 0.0235 & 0.29 \\
\hline Business angel networks & 0.8960 & 0.4338 & 4.2650 & 0.0389 & 2.45 \\
\hline Guarantee schemes & 0.4739 & 0.2262 & 4.3915 & 0.0361 & 1.60 \\
\hline Business consulting centers & 0.4110 & 0.1684 & 5.9584 & 0.0146 & 1.51 \\
\hline
\end{tabular}

Table 5. includes Investment in Machinery and Technical Equipment (IMTE) model. The most supportive institutions are technology parks, technology transfer centers, and business consulting centers -2 times increase of odds.

Table 5. Investment in Machinery and Technical Equipment (IMTE) model.

\begin{tabular}{|l|c|c|c|c|c|}
\hline \multicolumn{7}{|c|}{ Chi-square $=\mathbf{3 6 . 1 2 4}$, P-value $=\mathbf{0 . 0 0 0 0}$} \\
\hline Variable & Coefficient & $\begin{array}{c}\text { Standard error } \\
\text { (SE) }\end{array}$ & $\begin{array}{c}\text { Wald chi- } \\
\text { square }\end{array}$ & P-value & $\begin{array}{c}\text { Odds } \\
\text { ratio }\end{array}$ \\
\hline Technology parks & 0.6985 & 0.2587 & 7.2889 & 0.0069 & 2.01 \\
\hline $\begin{array}{l}\text { Technology transfer } \\
\text { centers }\end{array}$ & 0.7029 & 0.2711 & 6.7206 & 0.0095 & 2.02 \\
\hline $\begin{array}{l}\text { Business consulting } \\
\text { centers }\end{array}$ & 0.6983 & 0.1725 & 16.3769 & 0.0000 & 2.02 \\
\hline
\end{tabular}

Table 6. includes Investment in Computer Software (ICS) model. Thanks to technology transfer centers the odds of investments in computer software increase m0re than 3 times. In contrast, firms cooperating with both technology parks and business consulting centers have about 2 times higher odds to invest in computer software. 
Table 6. Investment in Computer Software (ICS) model.

\begin{tabular}{|c|c|c|c|c|c|}
\hline \multicolumn{6}{|c|}{ Chi-square $=47.344$, P-value $=0.0000$} \\
\hline Variable & Coefficient & $\begin{array}{c}\text { Standard error } \\
\text { (SE) }\end{array}$ & $\begin{array}{l}\text { Wald chi- } \\
\text { square }\end{array}$ & $\begin{array}{c}\text { P- } \\
\text { value }\end{array}$ & $\begin{array}{l}\text { Odds } \\
\text { ratio }\end{array}$ \\
\hline Technology parks & 0.7100 & 0.2556 & 7.7130 & 0.0055 & 2.03 \\
\hline $\begin{array}{l}\text { Technology transfer } \\
\text { centers }\end{array}$ & 1.1108 & 0.2944 & 14.2395 & 0.0002 & 3.04 \\
\hline $\begin{array}{l}\text { Business consulting } \\
\text { centers }\end{array}$ & 0.6967 & 0.1700 & 16.7922 & 0.0000 & 2.01 \\
\hline
\end{tabular}

Table 7. includes Launching New Products (LNP) model. Cooperation with technology transfer centers increases 2.5 times the odds of launching new products whereas business consulting centers boost the odds 1.5 times.

Table 7. Launching New Products (LNP) model.

\begin{tabular}{|l|c|c|c|c|c|}
\hline \multicolumn{7}{|c|}{ Chi-square $=\mathbf{2 8 . 0 0 1}$ P-value $=\mathbf{0 . 0 0 0 0}$} \\
\hline Variable & Coefficient & $\begin{array}{c}\text { Standard error } \\
\text { (SE) }\end{array}$ & $\begin{array}{c}\text { Wald chi- } \\
\text { square }\end{array}$ & $\begin{array}{c}\text { P- } \\
\text { value }\end{array}$ & $\begin{array}{c}\text { Odds } \\
\text { ratio }\end{array}$ \\
\hline Technology parks & 0.7330 & 0.2729 & 7.2141 & 0.0072 & 2.08 \\
\hline $\begin{array}{l}\text { Technology transfer } \\
\text { centers }\end{array}$ & 0.9259 & 0.3018 & 9.4087 & 0.0022 & 2.52 \\
\hline $\begin{array}{l}\text { Business consulting } \\
\text { centers }\end{array}$ & 0.4131 & 0.1732 & 5.6890 & 0.0170 & 1.51 \\
\hline
\end{tabular}

Table 8. includes New Technology Processes (INTP) model. Firms cooperating with business consulting centers and both technology parks and technology transfer centers have about 3.03-3.30 times higher odds to introduce new technology processes than firms having no contacts with those instruments.

Table 8. Implementation of New Technology Processes (INTP) model.

\begin{tabular}{|l|c|c|c|c|c|}
\hline \multicolumn{1}{|c|}{ Chi-square $=\mathbf{6 6 . 1 8 5}$, P-value $=\mathbf{0 . 0 0 0 0}$} \\
\hline Variable & Coefficient & $\begin{array}{c}\text { Standard error } \\
(\text { SE })\end{array}$ & $\begin{array}{c}\text { Wald chi- } \\
\text { square }\end{array}$ & $\begin{array}{c}\text { P- } \\
\text { value }\end{array}$ & $\begin{array}{c}\text { Odds } \\
\text { ratio }\end{array}$ \\
\hline Technology parks & 1.1086 & 0.3493 & 10.0693 & 0.0015 & 3.03 \\
\hline $\begin{array}{l}\text { Technology transfer } \\
\text { centers }\end{array}$ & 1.1128 & 0.3670 & 9.1920 & 0.0024 & 3.04 \\
\hline Guarantee schemes & 0.8149 & 0.2840 & 8.2307 & 0.0041 & 2.26 \\
\hline $\begin{array}{l}\text { Business consulting } \\
\text { centers }\end{array}$ & 1.1932 & 0.2216 & 29.0015 & 0.0000 & 3.30 \\
\hline
\end{tabular}

Table 9. includes New Production Methods (INPM) model. Firms cooperating with technology parks and technology transfer centers have about 1,65-2 times higher odds to implement new production methods.

Table 9. Implementation of New Production Methods (INPM) model.

\begin{tabular}{|l|c|c|c|c|c|}
\hline \multicolumn{7}{|c|}{ Chi-square $=\mathbf{1 7 . 6 5 7}$, P-value $=\mathbf{0 . 0 0 0 2}$} \\
\hline Variable & Coefficient & Standard error (SE) & $\begin{array}{c}\text { Wald chi- } \\
\text { square }\end{array}$ & P-value & $\begin{array}{c}\text { Odds } \\
\text { ratio }\end{array}$ \\
\hline Technology parks & 0.6943 & 0.2141 & 10.5195 & 0.0012 & 2.00 \\
\hline $\begin{array}{l}\text { Technology transfer } \\
\text { centers }\end{array}$ & 0.5013 & 0.2224 & 5.0787 & 0.0242 & 1.65 \\
\hline
\end{tabular}

Source: own study 
Table 10. includes Non Production Systems (INPS) model. Both guarantee schemes and business consulting centers increase more than 2.3 times odds to implement non production systems.

Table 10. Implementation of Non Production Systems (INPS) model.

\begin{tabular}{|c|c|c|c|c|c|}
\hline \multicolumn{6}{|c|}{ Chi-square $=50.803, P$-value $=0.0000$} \\
\hline Variable & Coefficient & Standard error (SE) & $\begin{array}{l}\text { Wald chi- } \\
\text { square }\end{array}$ & P-value & $\begin{array}{l}\text { Odds } \\
\text { ratio }\end{array}$ \\
\hline Technology parks & 0.7360 & 0.2130 & 11.9358 & 0.0006 & 2.09 \\
\hline Guarantee schemes & 0.8401 & 0.2138 & 15.4417 & 0.0000 & 2.32 \\
\hline $\begin{array}{l}\text { Business consulting } \\
\text { centers }\end{array}$ & 0.8410 & 0.1588 & 28.0335 & 0.0000 & 2.32 \\
\hline
\end{tabular}

Table 11. includes New Support Systems (INSS) model. Firms cooperating technology centers have 2.15 times higher odds to implement new support systems.

Table 11. Implementation of New Support Systems (INSS) model.

\begin{tabular}{|l|c|c|c|c|c|}
\hline \multicolumn{6}{|c|}{ Chi-square $=\mathbf{3 9 . 0 1 4}$, P-value $=\mathbf{0 . 0 0 0 0}$} \\
\hline Variable & Coefficient & $\begin{array}{c}\text { Standard } \\
\text { error (SE) }\end{array}$ & $\begin{array}{c}\text { Wald chi- } \\
\text { square }\end{array}$ & $\begin{array}{c}\text { P- } \\
\text { value }\end{array}$ & $\begin{array}{c}\text { Odds } \\
\text { ratio }\end{array}$ \\
\hline Technology parks & 0.6277 & 0.2164 & 8.4117 & 0.0037 & 1.87 \\
\hline Technology transfer centers & 0.7664 & 0.2252 & 11.5829 & 0.0007 & 2.15 \\
\hline Business consulting centers & 0.6356 & 0.1625 & 15.2926 & 0.0001 & 1.89 \\
\hline
\end{tabular}

Table 12. shows innovation activity grouped by BSIs. Technology parks, business consulting centers, and technology transfer centers are the most supportive instruments of facilitating all kinds of innovation activity. In contrast, the impact of university incubations and local or regional loan funds is not significant. The impact of technology incubations is positive in the area of R\&D and negative in the area of investment in buildings and land. On the other hand, business consulting centers and angel networks influence is significant regarding investments in buildings and land what may suggest that private investors are only interested in capitalizing relatively secure activities. Public guarantee schemes increase odds of investments and implementations but do not support high-risk activities (e.g., R\&D, LNP).

Table 12. Innovation activity by BSIs.

\begin{tabular}{|c|c|c|c|c|c|c|}
\hline $\begin{array}{c}\text { Innovation } \\
\text { Activity }\end{array}$ & $\begin{array}{c}\text { Technology } \\
\text { parks }\end{array}$ & $\begin{array}{c}\text { Technology } \\
\text { incubators }\end{array}$ & $\begin{array}{c}\text { Technology } \\
\text { transfer } \\
\text { centers }\end{array}$ & $\begin{array}{c}\text { Business } \\
\text { angel } \\
\text { networks }\end{array}$ & $\begin{array}{c}\text { Guarantee } \\
\text { schemes }\end{array}$ & $\begin{array}{c}\text { Business } \\
\text { consulting } \\
\text { centers }\end{array}$ \\
\hline R\&D & 2.60 & 2.55 & 3.17 & -- & -- & 1.42 \\
\hline INFA & 2.36 & -- & 1.87 & -- & 2.91 & 1.87 \\
\hline IBL & 1.86 & 0.29 & -- & 2.45 & 1.60 & 1.51 \\
\hline IMTE & 2.01 & -- & 2.02 & -- & -- & 2.02 \\
\hline ICS & 2.02 & -- & 3.04 & -- & -- & 2.01 \\
\hline LNP & 2.08 & -- & 2.52 & -- & -- & 1.51 \\
\hline INTP & 3.03 & -- & 3.04 & -- & 2.26 & 3.30 \\
\hline INPM & 2.00 & -- & 1.65 & -- & -- & -- \\
\hline INPS & 2.09 & -- & -- & -- & 2.32 & 2.32 \\
\hline INSS & 1.87 & -- & 2.15 & -- & -- & 1.89 \\
\hline
\end{tabular}




\section{Conclusions}

BSIs have a positive impact on innovation activity of medium-high and high technology manufacturers in Poland. Technology parks and business consulting centers are the most supportive. However, the strength of their impact is diversified as it ranges from 1.4 times in case of business consulting centers and R\&D expenditure to 3.3 times in case of business consulting centers and implementation of new technological processes. In contrast, technology incubators decrease odds of investment in buildings and land. The study confirms the low activity of university incubators what is inconsistent with results from developed countries [45] and requires more studies. The study has numerous limitations as it does not cover firm size, firm capital and the differentiation of regions [46]. Moreover, it concerns the innovation at the company level. It would be very interesting to extend the research about born global firms [47]. Furthermore, the study does not take into account the existence of a technological and demand gap between regions in Poland or/and between Poland and more developed countries. The further research can include constructing models with such variables as firm size, regional development or industry. The results show a static picture of the impact of business support institutions. However, the study does not take into account the dynamics between institutions and innovation activity. In order to illustrate these relationships, it would be advisable to use a network analysis that would show the impact of individual institutions on each of the activities.

\section{References}

1. M. Cowling, E. Ughetto, N. Lee, Technol. Forecast Soc., 127, 166-176 (2018)

2. T. Ratinho, E. Henriques, Technovation, 30, 278-290 (2010)

3. M. Schwartz, C. Hornych, Technovation, 30, 485-495 (2010)

4. D.B. Audretsch, E.E. Lehmann, M. Wright, J. Technol. Transfer, 39, 301-312 (2014)

5. R. Grimaldi, A. Grandi, Technovation, 25, 111-121 (2005)

6. M. Squicciarini, J. Technol. Transfer, 33, 45-71 (2008)

7. T. Clausen, T. Komeliussen, Technovation, 32, 560-567 (2012)

8. A. Bøllingtoft, Technovation, 32, 304-315 (2012)

9. F.C.C. Koh, W.T.H. Koh, F.T. Tschang, J. Bus. Venturing, 20, 217-239 (2005)

10. A. Saxenian, MITS Technol. Rev., 97, 42-51 (1994)

11. L. Rothschild, A. Darr, Technovation, 25, 59-67, (2005)

12. A. Bąkowski, M. Mażewska, J. Rudawska, A. Tórz, D. Trzmielak, Ośrodki innowacji i przedsiębiorczości w Polsce Raport 2018 (2018)

13. A. Kawa, M. Matusiak, Problemy Zarzadzania, 14, 98-119 (2016)

14. L. Puslecki, P. Trapczynski, M. Staszkow, J. East Eur. Manag. Stud., 21, 139-166 (2016)

15. L. Siemieniuk, Oeconomia Copernicana, 7, 143-159 (2016)

16. S. Mian, W. Lamine, A. Fayolle, Technovation, 50-51, 1-12 (2016)

17. D.N. Allen, S. Rahman, J. Small Bus. Manage., 23, 12-22 (1985)

18. L. Peters, M. Rice, M. Sundararajan, J. Technol. Transfer, 29, 83-91 (2004)

19. M. Hughes, R.D. Ireland, R.E. Morgan, Long Range Plann., 40, 154-177 (2007)

20. A. Bergek, C. Norman, Technovation, 28, 20-28 (2008)

21. S.M. Hackett, D.M. Dilts, J. Technol. Transfer, 29, 55-82 (2004) 
22. K. Aerts, P. Matthyssens, K. Vandenbempt, Technovation, 27, 254-267 (2007)

23. R. Aernoudt, Small Bus. Econ., 23, 127-135 (2004)

24. J.L. Barbero, J.C. Casillas, M. Wright, A.R. Garcia, 39, 151-168 (2014)

25. S. Macdonald, R\&D Manage., 17, 25-37 (1987)

26. D.S. Siegel, P. Westhead, M. Wright, M. Small Bus. Econ., 20, 177-184 (2003)

27. P.H. Phan, D.S. Siegel, M. Wright, M. J. Bus. Venturing, 20, 165-182 (2005)

28. A. Albahari, S. Pérez-Canto, A. Barge-Gil, A. Modrego, Technol. Forecast Soc., 116, 13-28 (2017)

29. A.N. Berger, R.J. Rosen, G.F. Udell, J. Bank., Financ., 31, 11-33 (2007)

30. M. Boschi, A. Girardi, M. Ventura, J. Financ. Stabil., 15, 182-194 (2014)

31. M. Cowling, J. Siepel, Technovation, 33, 265-275 (2013)

32. E. Ughetto, G. Scellato, M. Cowling, Small Bus. Econ., 49, 319-337 (2017)

33. H. Waniak-Michalak, Success Factors of Loan and Guarantee Funds Supporting Smes in Poland (2016)

34. A. Croce, M. Guerini, E. Ughetto, J. Small Bus. Manage., 56, 208-228 (2018)

35. J. A. Schumpeter, Business Cycles. A Theoretical, Historical and Statistical Analysis of the Capitalist Process (1939)

36. C. Edquist, L. Hommen, M.D. McKelvey, Innovation and Employment: Process Versus Product Innovation (2001)

37. F. Damanpour, M.R. Walker, A.C. Avellaneda, J. Manage. Stud., 46, 650-675 (2009)

38. R.M. Walker, J. Publ. Adm. Res. Theor., 18, 591-615 (2008)

39. F. Damanpour, S. Gopalakrishnan, J. Manage. Stud., 38, 45-65 (2002)

40. P. Dzikowski, Acta Sci. Pol. Oeconomia, 17, 13-22 (2018)

41. S. Lemeshow, R.X. Sturdivant, Applied Logistic Regression (2013)

42. J.H. Aldrich, F.D. Nelson, Linear Probability, Logit, and Probit Models (1984)

43. T.F. Liao, Interpreting Probability Models. Logit, Probit, and Other Generalized Linear Models (1994)

44. A. Stanisz, Modele regresji logistycznej Zastosowania w medycynie, naukach przyrodniczych i społecznych (2016)

45. V. Lasrado, S. Sivo, C. Ford, T. O’Neal, I. Garibay, J. Technol. Transfer, 41, 205-219 (2016)

46. J. Gorączkowska, Equilibrium, 10, 137-156 (2015)

47. P. Dzikowski, J. Bus. Res., 85, 281-294 (2018) 